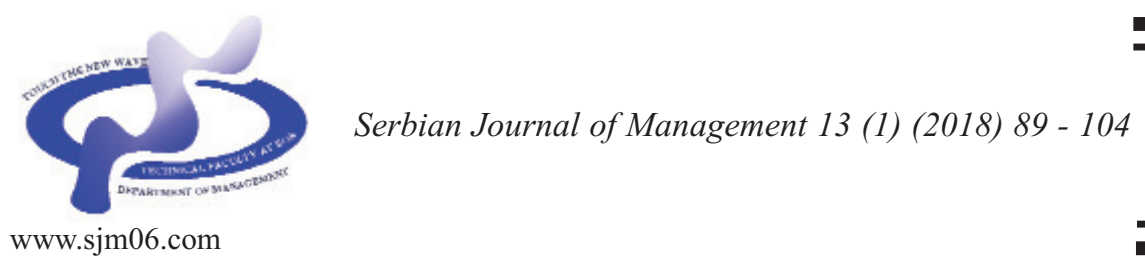

\title{
ENTREPRENEURIAL PERSONALITY TRAITS AND SMEs PROFITABILITY IN TRANSITION ECONOMY
}

\author{
Ivan Jovanović*, Milica Arsić and Đorđe Nikolić \\ University of Belgrade, Technical Faculty in Bor, Engineering Management Department, \\ Vojske Jugoslavije 12, 19210 Bor, Serbia
}

(Received 2 January 2017; accepted 21 June 2017)

\begin{abstract}
Creativity and innovation have been identified in the literature as the main drivers of small and medium size enterprises' development. The aim of this study was to determine whether these factors also affect the profitability of the SME sector in Serbia. The conceptual model was set and six hypotheses were proposed. The survey was conducted in South and South-Eastern Serbia, on a sample of 717 small and medium enterprises. Confirmatory Factor Analysis (CFA) and Path Analysis were used to test conceptual model. The results showed high reliability of the data and confirmed hypotheses.
\end{abstract}

Keywords: Entrepreneurship; Profitability SMEs; Statistical analysis; SEM methodology; Transitional economy

\section{INTRODUCTION}

Small and medium enterprises (SMEs) are regarded as important engines in the economic development of every country (Acs et al., 2008). The entrepreneurial orientation of SME owners has an important role in achieving this task. In their paper, authors Keh et al. (2007) showed that entrepreneurial orientation, with its three main dimensions: risk-taking, acting proactively and creativity, has a positive impact on the organizational performance and profitability. Organizations with a high level of entrepreneurial spirit constantly explore and analyze the environment in search for new ideas (Tang, 2008). It was also found that the majority of SMEs is interested in collecting information from the market regarding the customers' needs and

\footnotetext{
* Corresponding author: ijovanovic@tfbor.bg.ac.rs
}

DOI: $10.5937 /$ sjm13-13087 
competitors, in order to strengthen its market position and increase sale (Keh et al., 2007).

The aim of this study was to determine the mechanisms by which entrepreneurial activities and traits (entrepreneurial creativity, knowledge transfer, entrepreneurial self-efficacy, data collection, teamwork and organization' innovativeness) affect the profitability of SMEs in Serbia. Serbia was chosen for this study due to the fact that it was among the first Balkan countries restructured to a market economy during the 1990s. Since then, Serbia has been going through a transitional period and is currently a candidate for the membership in the EU. During that period a lot of things happened in Serbia which had different impact on the performance of organizations compared to the changes the countries with stable economies were undergoing. According to authors' knowledge not many research were done regarding SMEs activity in Serbia. Statistical Office of the Republic of Serbia conducted survey for period 20042006 on innovation activity in SMEs in Serbia and the results have shown that SMEs are faced with a large number of obstacles which adversely affect their activities (Nikolić et al., 2015). In their paper Cvetanović et al. (2014) applied multicriteria analysis in order to investigate the impact of information technologies on SME innovativeness and further on productivity growth and competitiveness. The authors of the study did not find the research that investigate the similar aspects, therefore this paper makes an attempt to identify the key factors which affect SMEs' profitability in Serbia. South and South-East Serbia was chosen as one of the less developed part of Serbia and future research will include other regions in Serbia. The results obtained from this region will be analyzed and compared to the results obtained from other regions, establishing thus universally valid connections that might be important for the development of entrepreneurship in Serbia.

Although in his work Naude (2010) underlined that research in the field of entrepreneurship should be limited only to the developed economies, Engelen et al. (2009) pointed out that similar researches in various cultures would only promote and improve entrepreneurship, because they could highlight links that were valid in relation to the links that applied to individual cultures. Also, some authors (LeskovarSpacapan \& Bastic, 2007) emphasized the transferability of conclusions across countries, and pointed out that the conclusions driven for developed countries could not be generalized and were not necessarily relevant for explaining situations in transition and developing countries.

In Serbia, the transition from centrally planned to a market-oriented economy was a radical change, making it impossible for companies to simultaneously carry out the internal reorganization and to successfully adapt to new environmental conditions. Although transition economies are becoming more similar to Western economies, however, the competitive ability of some organizations still remains limited by the legacy of the previous political and economic system. The way the organizations used to operate is no longer in accordance with modern way of doing business that requires flexibility, strengthening the innovative capacity and entrepreneurial spirit.

Taking all the previously stated into consideration, a conceptual model was developed and six hypotheses were proposed, which explore the factors affecting the profitability of SMEs. 
2. RESEARCH HYPOTHESES AND following hypothesis:

\section{THE CONCEPTUAL MODEL}

\subsection{An entrepreneur's creativity and organizational innovativeness}

Schumpeter (1934) in his theory of "creative destruction" stressed the key role of entrepreneurial creativity in initiating and developing technological innovation and economic changes. Since then, many studies have been examining the phenomenon of entrepreneurial creativity. Maslow (1968) underscored that creativity was an inherent feature of all people, but only a small part of the population used that creativity. Nystrom (1993) said that entrepreneurial creativity was "an invention of the future". In their study, Baron and Tang (2011) emphasized the positive impact of the entrepreneurial creativity on the organizations' performance. Entrepreneurial creativity can be defined as the creation of new and useful ideas in any domain (Amabile et al., 1996). People who are creative in one area are, probably, also creative in other areas, just as people who are highly intelligent have good results in any cognitive tasks (Nunnally, 1978; Silvia et al., 2009). Creative individuals are important in an organization for achieving sustainable and competitive advantages (Shalley, 1995), but also their presence can create a spillover effect and they can act as role models for the rest of employees (Shalley \& Gilson, 2004).

Innovation is a key element of competition and dynamic efficiency of the market (Hall et al., 2009). In the long run, an innovative organization will grow faster, be more efficient and more profitable compared to a non-innovative one. Our expectations are that the entrepreneurial creativity is positively related to organization innovativeness, therefore we suggest the
H1. Entrepreneurial creativity has positive impact on organizations' innovativeness.

\subsection{Knowledge transfer and organizations' innovativeness}

In organizational terms, knowledge transfer is a process in which the experience of one group affects the second group, having in mind that this process involves two or more parties (Hasan et al., 2013), and these parties are organizational units. In organizations where there is good communication between employees, knowledge transfer is something normal and happens indirectly (Sparkes \& Miyake, 2000). Organizations themselves are not capable of creating knowledge because knowledge is created by individuals, and it doubles the moment individuals share it with others (Zhang \& Ng, 2012). Knowledge transfer is better when there are no intermediaries in the relationship between two organizational units (Hansen, 2002).

Proper knowledge transfer enhances organizations' innovativeness, and thus the organizational performance (Szulanski, 1996). Soo et al. (2007) underlined that each organization would improve its performance if they were able to absorb knowledge, use that knowledge, act creatively by this knowledge and at the end, create new knowledge. Our expectation is that knowledge transfer will increase organizations' innovativeness and thus their profitability, so we suggest the hypothesis:

H2. Knowledge transfer has positive impact on organizations' innovativeness. 


\subsection{Entrepreneurial self-efficiency and team work}

Entrepreneurial self-efficacy refers to the extent to which an individual believes that he/she can complete tasks and roles of entrepreneurship (Boyd \& Vozikis, 1994). Entrepreneurs with the same skills may have weak, normal or outstanding performance, depending on whether their own beliefs about the self-efficacy strengthen or diminish their motivation and attempts to solve the problem (Wood \& Bandura, 1989). There are higher chances that individuals with high self-efficacy for a specific task will seek and stay on this task longer than individuals with low self-efficacy (Bandura, 2001). A person may have high self-efficacy in one area, but low self-efficacy in other areas, especially pertaining to certain, very specific tasks and/or skills (Wilson et al., 2007). Entrepreneurs with strong beliefs about their entrepreneurial self-efficacy tend to associate challenging situations with awards such as profit, recognition and psychological fulfillment, because selfefficacy is not related to the past, but to what could be achieved in the future (Hmieleski \& Corbett 2008; Yang \& Cheng, 2009).

According to Bandura (1977), there are four sources of information that are associated with self-efficacy: current effect, observation of another's behavior, support from others, especially important people, and emotional excitement or anxiety in contact with a certain type of behavior. In homogenous groups people with high level of self-efficacy are encouraged to be even more self-efficient. Our expectations are that the entrepreneurial self-efficacy has a positive impact on teamwork, and thus on better business performance, hence we propose the following hypothesis:
H3. Entrepreneurial self-efficacy has a positive impact on teamwork

\subsection{Data collection and team work}

Information from the market is defined as data related to the current and potential stakeholders, stemming from various external sources (Moorman, 1995). In their paper, Kawakami et al. (2012) underpinned that the importance of the data collection process was enormous for both large and SMEs. Data collection is a big challenge for SMEs, because of the limited resources at their disposal and less experience in market research. Therefore, most entrepreneurs rely on informal sources of information, such as relatives or existing customers (Narver \& Slater, 1990). Training and additional education of employees will enable employees to collect and use information from the market (Kawakami et al., 2012).

Quality decision making requires the integration of large amounts of knowledge dispersed throughout the firm (Grant, 1997). This means that those who have to make decisions first have to find the information within the organization, and then to transfer that knowledge to work teams when necessary (Dougherty, 2001). Internal learning in combination with external (fairs, exhibitions, seminars, training programs) creates the necessary precondition for successful teamwork in the organization, and thus the conditions for quality decisionmaking. We expect that the systematic collection of market information will have a positive effect on teamwork in the organization, and we suggest the following hypothesis:

H4. Data collection has positive impact on team work. 
2.5. Organizational innovativeness and profitability

SMEs that have previous experience in innovative activities have higher chances to be successful than non-innovative firms (European Commission, 2010). In many studies, there is evidence suggesting a positive relationship between the organizational innovativeness and performance of organizations, both in production and in service companies (Golovko \& Valentini, 2011; Love \& Roper, 2015). The same authors emphasized the positive impact of innovations in SMEs to their profitability, the growth of the organizations and increased export. We suggest the following hypothesis:

H5. Organizational innovativeness has positive impact on profitability.

\subsection{Team work and profitability}

The basic elements of each organizational unit are people and teams. By using teamwork organizations achieve synergetic effect, because higher scores are achieved working together rather than any individual

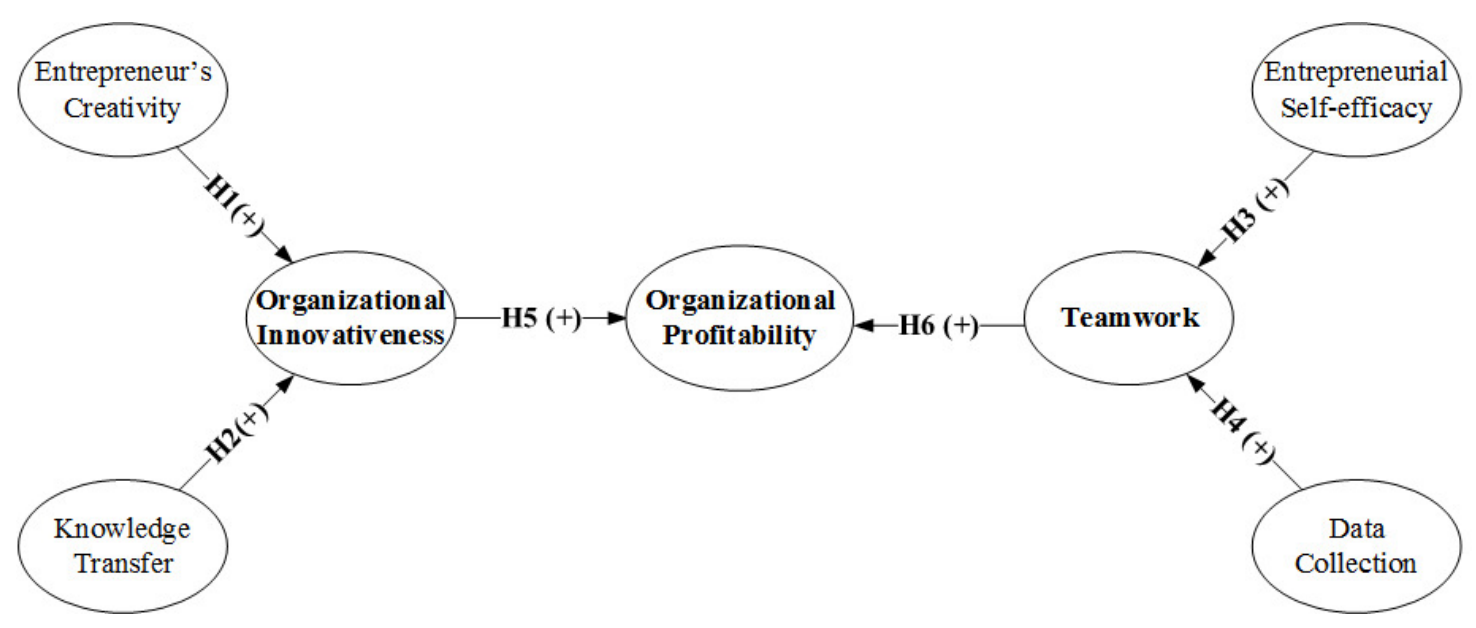

contribution, and also each individual in a team achieves more than he/she ever could (Tata \& Prasad, 2004). Today, teamwork is becoming important increasingly and modern business without it is almost unimaginable.

In almost all studies it was confirmed that teamwork increased employees' satisfaction and loyalty (Stewart \& Barrick, 2000) and leads organization closer to the set goals. Using teams is a part of social responsibility, because it enhances communication, trust and stimulates profitability (Levine, 2007). We suggest the following hypothesis:

H6. Teamwork has positive impact on organizational profitability.

According to hypotheses $\mathrm{H} 1-\mathrm{H} 6$, the conceptual model has been defined to measure the influence of certain parameters on the organizational profitability (Figure 1).

\section{METHODOLOGY}

The questionnaire consists of two parts. The first part comprises 8 control questions (Table 2) and second part contains 25 questions divided into 7 groups, which are related to entrepreneurial creativity,

Figure 1. Conceptual model 
innovativeness and organizational profitability (Table 1). For the assessment of the answers, we used a five-point Likert scale, where 1 means "strongly disagree"; 3 , "neutral" and 5, "strongly agree".

\subsection{Sample and data collection}

This research was conducted from January to May 2015, in South and SouthEastern Serbia. The authors personally conducted the survey, trying to explain the meaning of every issue to every respondent, in order to avoid misunderstanding. The survey was anonymous, but either way there were some respondents who did not want to fill out a survey. Survey covered a total of 856 small business owners, 717 questionnaires were properly completed (83.76\%). Ratio between sample size (717) and number of questions (25 from questionnaire) is 26.68 and is much larger than the prescribed value 5 (Hair et al., 2006).

\subsection{Demographic characteristics of the sample}

In the model, there are four independent variables: entrepreneurial creativity (Q1), knowledge transfer (Q2), entrepreneurial self-efficacy (Q3) and data collection (Q4),

\section{Table 1. Questionnaire items}

\begin{tabular}{|c|c|c|c|}
\hline Construct & Question & Description & Source \\
\hline \multirow{2}{*}{$\begin{array}{l}\text { Entrepreneurial } \\
\text { Creativity }\end{array}$} & Q1_1 & I invent exceptional and surprising solutions & \multirow{5}{*}{$\begin{array}{l}\text { Hills et al. } \\
(1997)\end{array}$} \\
\hline & Q1_2 & My ideas are usually very unique & \\
\hline \multirow[t]{3}{*}{ (Q1) } & Q1_3 & When I encounter obstacles, I am able to detour around them & \\
\hline & Q1_4 & I try to find novel solutions even it is not expected from me & \\
\hline & Q1_5 & I have a tremendous amount of ideas & \\
\hline \multirow{3}{*}{$\begin{array}{l}\text { Knowledge } \\
\text { Transfer } \\
\text { (Q2) }\end{array}$} & Q2_1 & $\begin{array}{l}\text { The company has a formal mechanisms to guarantee the sharing of the best } \\
\text { practices among the different fields of the activity }\end{array}$ & \multirow{3}{*}{$\begin{array}{l}\text { Jiménez - } \\
\text { Jiménez \& } \\
\text { Sanz-Valle } \\
(2011)\end{array}$} \\
\hline & Q2_2 & $\begin{array}{l}\text { There are individuals within the organization who take part in several teams or } \\
\text { divisions and who also act as links between them }\end{array}$ & \\
\hline & Q2_3 & $\begin{array}{l}\text { There are individuals responsible for collecting, assembling and distributing } \\
\text { internally employees' suggestions }\end{array}$ & \\
\hline \multirow{2}{*}{$\begin{array}{l}\text { Entrepreneurial } \\
\text { Self-efficacy }\end{array}$} & Q3_1 & I am able to set and attain profit objectives & \multirow{4}{*}{$\begin{array}{l}\text { Chen et al. } \\
\text { (1998) }\end{array}$} \\
\hline & Q3_2 & I am able to control costs & \\
\hline \multirow[t]{2}{*}{ (Q3) } & Q3_3 & I am able to conduct market analysis & \\
\hline & Q3_4 & I am able to develop new ideas & \\
\hline Data Collection & Q4_1 & $\begin{array}{l}\text { I gathered a lot of information on industries and sales etc. for the basis of the } \\
\text { business idea }\end{array}$ & \multirow[t]{3}{*}{$\begin{array}{l}\text { Heinonen } \\
\text { et al. (2011) }\end{array}$} \\
\hline \multirow[t]{2}{*}{ (Q4) } & Q4_2 & I gathered a lot of information on markets for the basis of the business idea & \\
\hline & Q4_3 & I did organised work on the business idea & \\
\hline \multirow{3}{*}{$\begin{array}{c}\text { Organizational } \\
\text { innovativeness } \\
\text { (Q5) }\end{array}$} & Q5_1 & $\begin{array}{l}\text { The number of firm's new products that are first-to-market (or early market } \\
\text { entrants) }\end{array}$ & \multirow{3}{*}{$\begin{array}{l}\text { Yang \& } \\
\text { Cheng } \\
(2009)\end{array}$} \\
\hline & Q5_2 & $\begin{array}{l}\text { The number of new products and/or services a firm has introduced to the } \\
\text { market }\end{array}$ & \\
\hline & Q5_3 & The speed of firm' new product and/or service development & \\
\hline Teamwork & Q6_1 & Assistance in developing new ideas is readily available & \multirow{4}{*}{$\begin{array}{l}\text { Anderson \& } \\
\text { West (1998) }\end{array}$} \\
\hline \multirow[t]{3}{*}{ (Q6) } & Q6_2 & $\begin{array}{l}\text { People in this team are always searching for fresh, new ways of looking at } \\
\text { problems }\end{array}$ & \\
\hline & Q6_3 & $\begin{array}{l}\text { The members of my team are always looking for new solutions and regard } \\
\text { every problem from a different perspective }\end{array}$ & \\
\hline & Q6_4 & People in the team co-operate in order to help develop and apply new ideas & \\
\hline \multirow{2}{*}{$\begin{array}{l}\text { Organizational } \\
\text { Profitability }\end{array}$} & Q7_1 & Our organization is doing much better business than our competition & \multirow[t]{3}{*}{ Authors } \\
\hline & Q7_2 & Our sales is increasing more than the competition's & \\
\hline (Q7) & Q7_3 & Our market share is larger than the competition's & \\
\hline
\end{tabular}


as well as three dependent latent variables: organizational innovativeness (Q5), teamwork (Q6) and the profitability (Q7). All these variables were measured using items adapted from published works that were relevant to our study (Hills et al., 1997; Anderson \& West, 1998; Chen et al., 1998; Yang \& Cheng, 2009; Heinonen et al., 2011; Jiménez - Jiménez \& Sanz-Valle, 2011), as shown in Table 1.

The demographic characteristics of the sample are described in Table 2 . The results have shown that survey included 504 male and 213 female entrepreneurs. 81.3\% from total number of respondents belong to the age group between 26-55, which represents the best period for entrepreneurship. According to the size of the company, $64.3 \%$ are owners of micro enterprises (less than 10 employees) and regarding the firm age, $75.2 \%$ are companies not older than 20 years, which is due to the fact that until 1990s economy in Serbia was centrally planned and SMEs started to develop during the transition period.

$66,5 \%$ of the total number of respondents said that they had had previous entrepreneurial experience, which means that $33.5 \%$ started a new venture. Out of those who said that they had had previous entrepreneurial experience, $86.6 \%$ (413/477) stated that in the past they had been doing the same business as they did now. Also, it is notable that $87.9 \%$ of organizations are domestically owned and $57.8 \%$ are service organizations.

\section{RESEARCH RESULTS}

\subsection{Descriptive statistics}

Descriptive statistics belongs to the group of statistical methods for research of mass phenomena, which includes collecting, sorting, calculating, displaying and

Table 2. Demographic characteristics of the sample

\begin{tabular}{|c|c|c|c|c|}
\hline Mark & Control variables & Category & Frequency & Share $(\%)$ \\
\hline \multirow{2}{*}{ CQ1 } & \multirow{2}{*}{ Gender } & male & 504 & 70.3 \\
\hline & & female & 213 & 29.7 \\
\hline \multirow{5}{*}{ CQ2 } & \multirow{5}{*}{ Age } & $\leq 25$ & 55 & 7.7 \\
\hline & & $2 \overline{6}-35$ & 148 & 20.7 \\
\hline & & $36-45$ & 239 & 33.3 \\
\hline & & $46-55$ & 196 & 27.3 \\
\hline & & $\geq 56$ & 79 & 11.0 \\
\hline \multirow{3}{*}{ CQ3 } & \multirow{3}{*}{ Number of employees } & $\leq 10$ & 461 & 64.3 \\
\hline & & $11-50$ & 175 & 24.4 \\
\hline & & $51-250$ & 81 & 11.3 \\
\hline \multirow{5}{*}{ CQ4 } & \multirow{5}{*}{ Firm age } & $\leq 5$ & 175 & 24.4 \\
\hline & & $6-10$ & 164 & 22.9 \\
\hline & & $11-20$ & 200 & 27.9 \\
\hline & & $21-30$ & 99 & 13.8 \\
\hline & & $\geq 31$ & 79 & 11.0 \\
\hline \multirow{2}{*}{ CQ5 } & \multirow{2}{*}{ Previous experience } & No & 240 & 33.5 \\
\hline & & Yes & 477 & 66.5 \\
\hline \multirow{2}{*}{ CQ6 } & \multirow{2}{*}{ Previous experience in industry } & No & 304 & 42.4 \\
\hline & & Yes & 413 & 57.6 \\
\hline \multirow{3}{*}{ CQ7 } & \multirow{3}{*}{ Source of capital } & Domestic capital & 630 & 87.9 \\
\hline & & Foreign capital & 49 & 6.8 \\
\hline & & Mixed capital & 38 & 5.3 \\
\hline \multirow{4}{*}{ CQ8 } & \multirow{4}{*}{ Industry } & Agriculture & 43 & 6.0 \\
\hline & & Manufacture & 168 & 23.4 \\
\hline & & Non-manufacture & 92 & 12.8 \\
\hline & & Service & 414 & 57.8 \\
\hline
\end{tabular}


Table 3. Descriptive statistics of variables

\begin{tabular}{|c|c|c|c|c|c|c|c|c|c|c|c|c|c|c|}
\hline $\begin{array}{l}\text { Vari- } \\
\text { abla }\end{array}$ & $\begin{array}{l}\mathrm{Me}- \\
\text { ans } \\
\end{array}$ & $\begin{array}{c}\text { Std. } \\
\text { Dev. }\end{array}$ & $\begin{array}{c}\text { Vari- } \\
\text { abla }\end{array}$ & $\begin{array}{r}\mathrm{Me}- \\
\text { ans } \\
\end{array}$ & $\begin{array}{c}\text { Std. } \\
\text { Dev. }\end{array}$ & $\begin{array}{l}\text { Vari- } \\
\text { abla }\end{array}$ & $\begin{array}{l}\mathrm{Me}- \\
\text { ans }\end{array}$ & $\begin{array}{l}\text { Std. } \\
\text { Dev. }\end{array}$ & $\begin{array}{c}\text { Vari- } \\
\text { abla }\end{array}$ & $\begin{array}{l}\mathrm{Me}- \\
\text { ans }\end{array}$ & $\begin{array}{c}\text { Std. } \\
\text { Dev. }\end{array}$ & $\begin{array}{l}\text { Vari- } \\
\text { abla }\end{array}$ & $\begin{array}{l}\mathrm{Me}- \\
\text { ans }\end{array}$ & $\begin{array}{l}\text { Std. } \\
\text { Dev }\end{array}$ \\
\hline Q1_1 & 3.9 & 0.90 & Q2_1 & 4.0 & 0.86 & Q3_3 & 3.7 & 0.95 & Q5_1 & 3.2 & 0.98 & Q6_3 & 3.8 & 0.89 \\
\hline Q1_2 & 3.8 & 0.90 & Q2_2 & 4.0 & 0.88 & Q3_4 & 4.0 & 0.83 & Q5_2 & 3.2 & 1.04 & Q6_4 & 3.9 & 0.92 \\
\hline Q1_3 & 4.0 & 0.81 & Q2_3 & 3.8 & 0.95 & Q4_1 & 3.2 & 1.22 & Q5_3 & 3.1 & 1.10 & Q7_1 & 3.5 & 0.92 \\
\hline Q1_4 & 3.6 & 1.02 & Q3_1 & 4.1 & 0.81 & Q4_2 & 3.3 & 1.10 & Q6_1 & 3.9 & 0.89 & Q7_2 & 3.4 & 0.90 \\
\hline Q1_5 & 4.0 & 0.90 & Q3_2 & 3.9 & 0.98 & Q4_3 & 3.0 & 1.15 & Q6_2 & 3.8 & 0.88 & Q7_3 & 3.4 & 0.92 \\
\hline
\end{tabular}

describing the main characteristics of the statistical series. Descriptive statistics was performed using software package SPSS 18.0. Results of descriptive statistics for all 25 questions (variables), are shown in Table 3.

Table 3 shows some basic parameters of descriptive statistics only: the mean value of the sample as a measure of central tendency and standard deviation.

\subsection{Factor analysis}

First we conducted an exploratory factor analysis to uncover the underlying factor structure and the distinctiveness of latent variables. Table 4 details the results of the analysis using Varimax rotation method with Kaiser Normalization. The rotated factor matrix generated 7 factors, with acceptable results $(\mathrm{KMO}=0,90, \quad \mathrm{p}<0,000)$. $\mathrm{PCA}$

Table 4. The results of the EFA and CFA statistics for measurement model

\begin{tabular}{|c|c|c|c|c|c|c|}
\hline \multirow{3}{*}{ Group } & \multirow{3}{*}{ Variable } & \multicolumn{2}{|c|}{$\begin{array}{c}\text { Exploratory Factor Analysis } \\
\text { (EFA) }\end{array}$} & \multicolumn{3}{|c|}{$\begin{array}{l}\text { Confirmatory Factor Analysis } \\
\text { (CFA) }\end{array}$} \\
\hline & & \multicolumn{2}{|l|}{ PCA } & \multirow{2}{*}{$\begin{array}{c}\text { Reliability } \\
\begin{array}{c}\text { Cronbach } \\
\text { alpha }\end{array}\end{array}$} & \multicolumn{2}{|c|}{ Convergent validity } \\
\hline & & $\begin{array}{c}\% \text { variance that can be } \\
\text { describe one-dimensional } \\
\text { factor }\end{array}$ & $\begin{array}{c}\text { Factor } \\
\text { loading }\end{array}$ & & $\begin{array}{c}\text { Factor } \\
\text { loading }\end{array}$ & $\mathrm{t}$-value \\
\hline \multirow{6}{*}{ Q1 } & & 58.38 & & 0.73 & & \\
\hline & Q1_1 & & 0.73 & & 0.63 & $13.49 * *$ \\
\hline & Q1_2 & & 0.70 & & 0.59 & $11.10 * *$ \\
\hline & Q1_3 & & 0.70 & & 0.60 & $13.47 * *$ \\
\hline & Q1_4 & & 0.68 & & 0.66 & $11.60 * *$ \\
\hline & Q1_5 & & 0.67 & & 0.61 & $13.41 * *$ \\
\hline \multirow{4}{*}{ Q2 } & & 68.86 & & 0.77 & & \\
\hline & Q2_1 & & 0.81 & & 0.65 & $13.73 * *$ \\
\hline & Q2_2 & & 0.86 & & 0.80 & $16.86 * *$ \\
\hline & Q2_3 & & 0.82 & & 0.74 & $14.86 * *$ \\
\hline \multirow{5}{*}{ Q3 } & & 64.81 & & 0.72 & & \\
\hline & Q3_1 & & 0.74 & & 0.58 & $14.11 * *$ \\
\hline & Q3_2 & & 0.72 & & 0.62 & $11.44 * *$ \\
\hline & Q3_3 & & 0.76 & & 0.64 & $13.00 * *$ \\
\hline & Q3_4 & & 0.74 & & 0.65 & $14.82 * *$ \\
\hline \multirow{4}{*}{ Q4 } & & 69.60 & & 0.78 & & \\
\hline & Q4_1 & & 0.86 & & 0.78 & $19.32 * *$ \\
\hline & Q4_2 & & 0.87 & & 0.77 & $19.12 * *$ \\
\hline & Q4_3 & & 0.77 & & 0.66 & $13.75 * *$ \\
\hline \multirow{4}{*}{ Q5 } & & 68.86 & & 0.84 & & \\
\hline & Q5_1 & & 0.81 & & 0.85 & $19.11 * *$ \\
\hline & Q5_2 & & 0.86 & & 0.77 & $19.44 * *$ \\
\hline & Q5_3 & & 0.82 & & 0.75 & $18.03 * *$ \\
\hline \multirow{5}{*}{ Q6 } & & 68.56 & & 0.85 & & \\
\hline & Q6_1 & & 0.81 & & 0.64 & $15.56 * *$ \\
\hline & Q6_2 & & 0.86 & & 0.74 & $18.58 * *$ \\
\hline & Q6_3 & & 0.81 & & 0.82 & $19.21 * *$ \\
\hline & Q6_4 & & 0.83 & & 0.67 & $16.10 * *$ \\
\hline \multirow{4}{*}{ Q7 } & & 78.88 & & 0.87 & & \\
\hline & Q7_1 & & 0.88 & & 0.84 & $18.30 * *$ \\
\hline & Q7_2 & & 0.90 & & 0.89 & $21.98 * *$ \\
\hline & Q7_3 & & 0.88 & & 0.84 & $19.86 * *$ \\
\hline
\end{tabular}

Notes: The level of statistical significance: $* \mathrm{p}<0.10 ; * * \mathrm{p}<0.05$ 
(Principal Components Analysis) has been conducted as the extracting method for each group of the defined model. Factor loadings and percent of explained variance by unidimensional factor extraction, are presented in the Table 4.

Before evaluating the fit of the conceptual model presented in Figure 1, it is necessary to define a measurement (control) model to verify that the 25 measurement variables written to reflect the seven unobserved constructs-groups, do so in a reliable manner. Important issues of defined model functionality are its validity and reliability. Therefore, Confirmatory Factor Analysis (CFA) was applied on all latent groups of the measurement model at the same time, forcing correlation relationship between 7 defined groups. The obtained values are shown in Table 4.

Although, PCA analysis had already uncovered unidimensionality within 7 groups, CFA with maximum likelihood estimation, confirmed that the overall measurement model fit appeared quite good. The reliability and fit measures of measurement model are also shown in Table 4.

The CFA parameters of unidimensionality and reliability (Cronbach 'salfa) of the scales, indicate that all the groups are unidimensional and highly reliable.
Furthermore, CFA was used to assess convergent validity (Živković et al., 2010) and if all factor loadings of indicators on their constructs were significant, convergent validity was attained. The values of factor loading, $t$-value and $p$-value $(p<0.05)$, shown in the Table 4, imply that all constructs have strong convergent validity.

A number of goodness-of-fit criteria are available to assess the overall fit of the models. Goodness-of-fit criteria measure the extent to which the actual or observed covariance input matrix corresponds to that predicted from the proposed model (Ho, 2006). Some commonly used measures of absolute fit include: goodness-of-fit index (GFI) and root-mean-square error of approximation (RMSEA). GFI is a nonstatistical measure ranging from 0 (poor fit) to 1 (perfect fit). The higher the value of GFI indicator, the better the match. Good fitting is indicated by a value above 0.90 (Molina et al., 2007). Therefore, this indicator is acceptable in our model (GFI $=0.85$ ), its value is just below the threshold, and it is assumed that it would increase with an increase in the number of respondents. Other indicators of correspondence of the model are given in Table 5.

Based on the obtained values of indicators (AGFI, CFI, IFI, NFI, NNFI and RFI), which are considered acceptable (values above

Table 5. The values of the indicator fitting for measuring and structural model

\begin{tabular}{|c|c|c|c|}
\hline Fit indicators & $\begin{array}{l}\text { Values for the control } \\
\text { (measurement) model }\end{array}$ & $\begin{array}{l}\text { Values for structural } \\
\text { (PATH) model }\end{array}$ & $\begin{array}{l}\text { Recommended } \\
\text { values }\end{array}$ \\
\hline Chi-Square $\left(\chi^{2}\right)$ & 583.14 & 651.47 & - \\
\hline Degree of freedom (d.f.) & 254 & 263 & - \\
\hline Relative Chi-Square ( $\chi^{2} /$ d.f. $)$ & 2.30 & 2.48 & $<3.0$ \\
\hline Root Mean Square Error of Approximation (RMSEA) & 0.07 & 0.07 & $<0.08-0.10$ \\
\hline Goodness-of-Fit Index (GFI) & 0.87 & 0.85 & $>0.8$ \\
\hline Adjusted Goodness-of-Fit Index (AGFI) & 0.83 & 0.82 & $>0.9$ \\
\hline Comparative Fit Index (CFI) & 0.97 & 0.97 & $>0.9$ \\
\hline Incremental Fit Index (IFI) & 0.97 & 0.97 & $>0.9$ \\
\hline Normed Fit Index (NFI) & 0.95 & 0.95 & $>0.9$ \\
\hline Non-Normed Fit Index (NNFI) & 0.97 & 0.96 & $>0.9$ \\
\hline Relative Fit Index (RFI) & 0.94 & 0.94 & $>0.9$ \\
\hline
\end{tabular}


0.90) we can conclude that the proposed model shows a solid increase of correspondence.

The final aspect to be studied is the proposed model's parsimony. Of the measurements proposed, only the relative chi-square is of use in the confirmatory analysis. This measurement must take values above one and below three or even five to ensure the data is not over fitted (Hair et al., 2006; Molina et al., 2007) and to be truly representative of the data. In our case, the value reached is 2.48 and therefore within the accepted limits.

\subsection{Correlation matrix}

Results of correlation analysis are shown in Table 6.
All the values of correlation coefficients should be above the recommended value of 0.33 . In this way it is ensured that there is a positive correlation between the latent variables.

\subsection{Path model}

The conceptual model was tested using software package LISREL 8.8. SEM analysis was chosen over regression analysis, because SEM can analyze all the paths in one analysis (Gefen et al., 2000; Tenenhaus et al., 2005; Živković et al., 2010).

The results of SEM analysis are shown in Figure 2. Regression coefficients are presented above the arrows and they explain the strength of the relationship between dependent and independent variables. It can

\section{Table 6. Correlation matrix of latent variables}

\begin{tabular}{|c|c|c|c|c|c|c|c|}
\hline Latent variables & 1 & 2 & 3 & 4 & 5 & 6 & 7 \\
\hline 1. Entrepreneur's creativity & 1 & & & & & & \\
\hline 2. Knowledge transfer & $0.46 *$ & 1 & & & & & \\
\hline 3. Entrepreneurial self-efficacy & $0.84 * *$ & $0.44 *$ & 1 & & & & \\
\hline 4. Data collection & $0.71 * *$ & $0.40 *$ & $0.71 * *$ & 1 & & & \\
\hline 5. Organizational innovativeness & $0.50 * *$ & $0.35^{*}$ & $0.38 *$ & $0.41 * *$ & 1 & & \\
\hline 6. Teamwork & $0.44 *$ & $0.54 * *$ & $0.35^{*}$ & $0.42 * *$ & $0.26 *$ & 1 & \\
\hline 7. Organizational Profitability & $0.49 * *$ & $0.49 * *$ & $0.48 * *$ & $0.36 * *$ & $0.65 * *$ & $0.37 * *$ & 1 \\
\hline
\end{tabular}

Notes: The level of statistical significance: $* p<0.10 ;{ }^{* *} p<0.05$

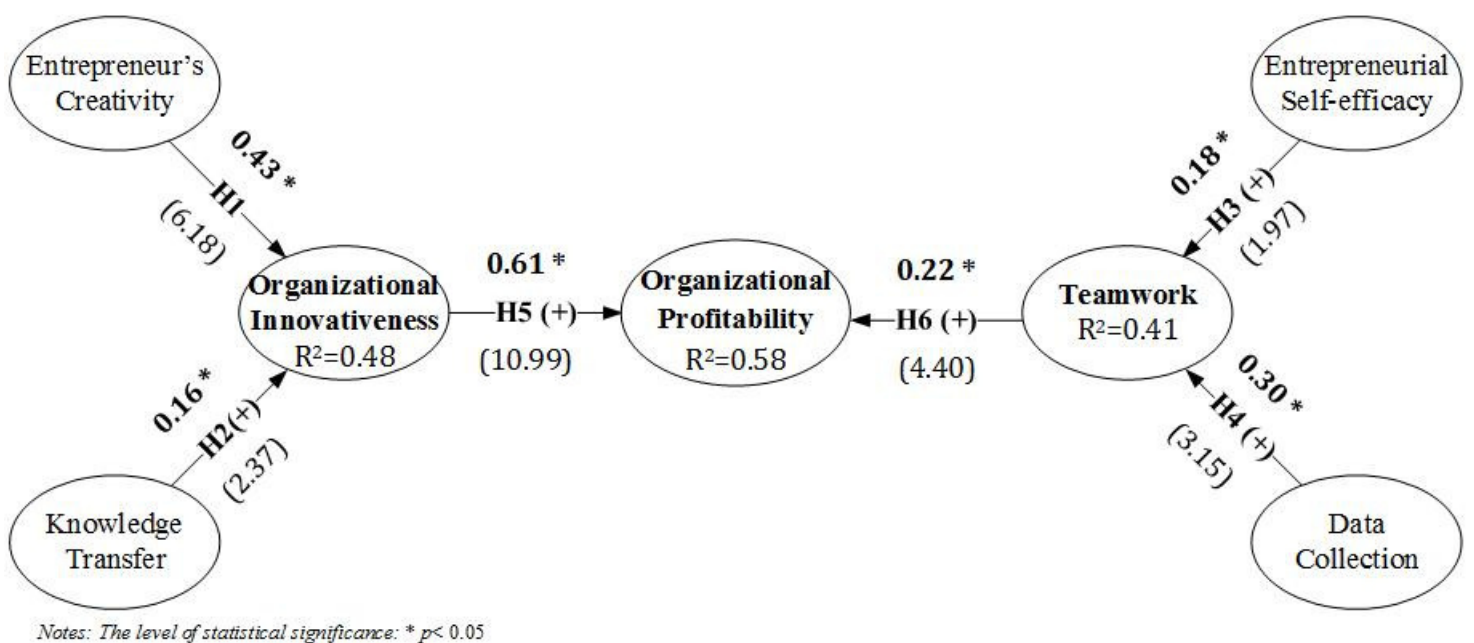

Figure 2. Structural (Path) model 
be seen that all coefficients have positive value, after that the t-test was performed in order to test statistical significance of the results. The results of the t-test demonstrated values over 1.96 as it had been prescribed (Hair et al., 2006; Ho, 2006), so we can conclude that all six hypothesis are confirmed.

The Squared Multiple Correlations $\left(\mathrm{R}^{2}\right)$ value represents the percentage of variance in an endogenous construct explained by other constructs connected to it directly. Interpreted as multiple regression results, the $\mathrm{R}^{2}$ value indicates the amount of variance explained by the model. The overall model explained $58 \%$ of the variance in organizational profitability.

\section{DISCUSSION}

Results of descriptive statistics (Table 3) show that the mean value of respondents' answers ranges from 3.0 to 4.1 , and standard deviation from 0.81 to 1.22 . Mean value for all 25 questions, is 3.67, and mean value for standard deviation is 0.95 . Based on these results it can be concluded that entrepreneurs have a positive opinion regarding all researched aspects and that they can meet all essential preconditions of entrepreneurial activities, which are defined in the model.

In all the groups (Q1-Q7) KMO indicators are far above the recommended value of 0.6. Bartlett indicator of sphericity is significant and lower than 0.05 , which indicates that there are correlations among the items in the questionnaire, that is, correlation matrix is not one. In this way, the results confirmed that the data set was suitable for factor analysis.

The results of factor analysis (PCA) confirmed unidimensionality in all groups of questions that were posted in the conceptual model, because all the test items grouped in one factor were set with eigenvalue greater than 1.0. Percentage of variability described by each factor is shown in Table 4 . The factor loading of variables is in the range from 0.67 to 0.90 , which is above the recommended value of 0.6. This suggests that the group of latent variables defined by Q1 to Q7, can be reliably described using research questions defined by Q1_1 to Q7_3.

Based on the results of the CFA analysis (Table 4) it can be seen that the values of Cronbach' alpha coefficient for all groups of questions is over the prescribed value 0.7. Also, Cronbach' alpha coefficient for the entire survey population was calculated $(\alpha=0.91)$ and is above the recommended values. These results suggest that there is an internal consistency and good possibility of modeling results for the survey population.

Table 5 shows comparative results for measurement and structural model. In the measurement model RMSEA indicator has a value of 0.07 , and in structural model 0.07 , indicating acceptable coincidence parameters of both models. GFI indicator also shows good correspondence for both measurement and structural models, with obtained values 0.87 and 0.85 , respectively. Based on RMSEA and GFI indicators, we can conclude that there is an absolute coincidence parameters of both models. Also, based on the obtained values of the indicator for measurement model $\mathrm{AGFI}=0.83 ; \mathrm{CFI}=0.97 ; \mathrm{IFI}=0.97 ; \mathrm{NFI}=0.95$; $\mathrm{NNFI}=0.97$ and $\mathrm{RFI}=0.94$, and structural model $\mathrm{AGFI}=0.82 ; \mathrm{CFI}=0.97 ; \quad \mathrm{IFI}=0.97$; $\mathrm{NFI}=0.95$; NNFI $=0.96$ and $\mathrm{RFI}=0.94$, whose values are acceptable and above 0.90 , we can conclude that both models demonstrate considerable increase of correspondence. 
The relative chi-square $\left(\chi^{2} /\right.$ d.f. $)$ of the measurement model is 2.30 , and 2.48 of the structural model, which fits in the recommended range from 1 to 3 . Thus it was confirmed that the initial data were truly representative.

Based on the results of the fit indicator it can be concluded that good fitting of both models (both measuring and structural) was achieved. Furthermore, a general conclusion can be made that all 25 variables (questions) can be a reliable and valid way to describe the formed 7 groups of latent variables (sets of questions) of the conceptual model, which is shown in Figure 1.

Results of SEM analysis (Figure 2) indicate that all six research hypotheses are confirmed since the following results were obtained: $\quad H 1(\beta=0.43, \quad \mathrm{t}=6.18, \quad \mathrm{p}<0.05)$; $\mathrm{H} 2(\beta=0.16, \mathrm{t}=2.37, \mathrm{p}<0.05) ; \mathrm{H} 3(\beta=0.18$, $\mathrm{t}=1.97, \quad \mathrm{p}<0.05) ; \quad \mathrm{H} 4(\beta=0.30, \quad \mathrm{t}=3.15$, $\mathrm{p}<0.05) ; \mathrm{H} 5(\beta=0.61, \mathrm{t}=10.99, \mathrm{p}<0.05)$ and H6 $(\beta=0.22, \mathrm{t}=4.40, \mathrm{p}<0.05)$. The Squared Multiple Correlations $\left(\mathrm{R}^{2}\right)$, in this study suggests that the effects of latent predictors "Entrepreneurial creativity" and "Knowledge transfer" on the latent endogenous variable "Organizations' innovativeness" can be explained with $48 \%$ of the variance. Latent endogenous variable "Teamwork" can be explained with $41 \%$ of the variance with latent predictors "Entrepreneurial selfefficacy" and "Data collection". In addition, the model explained $58 \%$ of "Organizations' profitability".

\section{CONCLUSION}

The transition from centrally planned to a market-oriented economy demanded some changes within the organization and in the external environment. The biggest efforts were made to create political and economic conditions in the country that would attract foreign capital but also enable people with capital in the country to launch their own small business. In all of these efforts to adjust the situation in the external environment little attention was given to people within the organization and to certain personality traits carrying with it the spirit of entrepreneurship. Entrepreneurship requires a high level of creativity, innovation and risk taking, everything not specific for Serbian national culture. Entrepreneurship was created in the Western culture and precisely reflects that way of thinking and doing business, which relies on creativity and innovation.

This research is a contribution to the field of entrepreneurship, related in particular to creativity and innovation. Serbia, which was mainly characterized by centrally planned and mono-structural economy until 2000, has a very short history of entrepreneurship. Similarly to all transition countries, entrepreneurship is still in its development in Serbia, due to economic conditions and also because of the national culture, which is not inherently risk-taking that is on the other hand inevitably linked to the concept of entrepreneurship.

The implications that this research could have on the business policy makers, and especially to those to which the research refers, for entrepreneurs, is that creativity and innovation must be encouraged. Maslow (1968) said that creativity was a personality trait that could be developed and nurtured. One of the biggest myths of entrepreneurship is that entrepreneurship cannot be taught. Yes, it can, considerably, we just have to learn to accept the risk that goes with it and every innovation introduced into the 
business. Although most entrepreneurs and small business owners have very little free time, however, they should find time for creative thinking and a positive attitude to change.

This research examined how owners' personality traits affected organizational profitability. As with any study, there are certain limitations. First of all, entrepreneurs evaluated their creativity and self-efficacy by themselves hence the entire investigation is based on their subjective assessment which must always be taken with a grain of salt. We tried to alleviate their subjectivity regarding the innovation, forcing them to selfassessment in relation to the biggest competitor. Future research could also reduce subjectivity using a different scale, which will exclude self-assessment of entrepreneurs. Another limitation was the fact that the survey was conducted in South and South-Eastern Serbia, which represents a less developed part of Serbia, thus the obtained results cannot be generalized for the entire country, but can be a good basis for further research in other regions, and used for their comparative analysis.

\section{References}

Acs, Z., Desai, S., \& Hessels, J. (2008). Entrepreneurship, economic development and institutions. Small Business Economics, 31 (3), 219-234.

Amabile, T. M., Conti, R., Coon, H., Lazenby, J., \& Herron, M. (1996). Assessing the work environment for creativity. Academy of Management Journal, 39 (5), 1154-1184.

Anderson, N. R., \& West M. A. (1998). Measuring climate for work group innovation: development and validation of the team climate inventory. Journal of organizational behavior, 19, 235-258.

Bandura, A. (1977). Self-efficacy: Toward a unifying theory of behavioral change. Psychology Review, 84, 191-215.

Bandura, A. (2001). Social cognitive theory: An agentic perspective. Annual Review of Psychology, 52 (1), 1-26.

Baron, R. A., \& Tang, J. (2011). The role of entrepreneurs in firm-level innovation: The joint effects of positive affect, creativity, and environmental dynamism. Journal of Business Venturing, 26 (1), 49-60.

Boyd, N. G., \& Vozikis, G. S. (1994). The influence of selfefficacy on the development of entrepreneurial intentions and actions. Entrepreneurship Theory and Practice, 18 (4), 63-77.

Chen, C. C., Greene, P. G., \& Crick, A. (1998). Does entrepreneurial self-efficacy distinguish entrepreneurs from managers? Journal of Business Venturing, 13 (4), 295 316.

Cvetanović, S., Nedić, V., \& Erić, M. (2014). Information technology as a determinant of SMEs collaboration and innovativeness. International Journal for Quality Research, 8 (4) 465-480.

Dougherty, D. (2001). Organizing practice-based knowledge in service organizations. Academy of Management Proceedings, paper TIM: C1.

Engelen, A., Heinemann, F., \& Brettel, M. (2009). Cross-cultural entrepreneurship research: Current status and framework for future studies. Journal of International Entrepreneurship, 7 (3), 163-189.

European Commission (2010). Internationalisation of European SMEs. Brussels: Directorate-General for Enterprise and Industry, European Commission.

Gefen, D., Straub, D., \& Boudreau, M. (2000). Structural equation modeling 


\title{
ЛИЧНЕ ПРЕДИЗЕТНИЧКЕ ОСОБИНЕ И ПРОФИТАБИЛНОСТ МСП У ТРАНЗИЦИОНОЈ ЕКОНОМИЈИ
}

\author{
Иван Јовановић, Милица Арсић и Ђорђе Николић
}

\section{Извод}

Креативност и иновације идентификовани су у литератури као главни покретачи развоја малих и средњих предузећа. Циљ ове студије је био да се утврди да ли ови фактори утичу и на профитабилност сектора МСП у Србији. Постављен је концептуални модел и предложено је шест хипотеза. Истраживање је спроведено у јужној и југоисточној Србији на узорку од 717 малих и средњих предузећа. Конфирматорна факторска анализа (КФА) и "Path Analysis" су коришћени за тестирање концептуалног модела. Резултати су показали високу поузданост података и потврђене су хипотезе.

Кључне речи: предузетништво, профитабилност МСП, статистичка анализа, СЕМ методологија, транзициона економија

techniques and regression: Guidelines for research practice. Journal of the Association for Information Systems, 4 (7), 1-70.

Golovko, E., \& Valentini, G. (2011). Exploring the complementarity between innovation and export for SMEs growth. Journal of International Business Studies, 42, 362-380.

Grant, R. M. (1997). The Knowledgebased View of the Firm: Implications for Management Practice. Long Range Planning, 30 (3), 450-454.

Hair, J. F., Black, W. C., Babin, B. J., Anderson, R. E., \& Tatham, R. L. (2006). Multivariate Data Analysis, 6th Edition, Pearson Prentice Hall, Upper Saddle River, NJ.

Hall, B. H., Lotti, F., \& Mairesse, J. (2009). Innovation and productivity in SMEs: Empirical evidence for Italy. Small Business Economics, 33, 13-33.

Hansen, M. T. (2002). Knowledge networks: Explaining effective knowledge sharing in multiunit companies.
Organization Science, 13 (3), 232-248.

Hasan, I., Low, P. K. C., \& Islam, M. Z. (2013). Knowledge management, Knowledge Transfer and Corporate Social Responsibility (CSR). Springer link: Encyclopedia of Corporate Social Responsibility, 1555-1562.

Heinonen, J., Hytti, U., \& Stenholm P. (2011). The role of creativity in opportunity search and business idea creation. Education \& Training, 53 (8/9), 659-672.

Hills, G. E., Lumpkin, G. T., \& Singh, R. P. (1997). Opportunity recognition: Perceptions and behaviors of entrepreneurs. Frontiers of Entrepreneurship Research, 17, 168-182.

Hmieleski, K. M., \& Corbett, A. C. (2008). The contrasting interaction effects of improvisational behaviour with entrepreneurial self-efficacy on new venture performance and entrepreneur work satisfaction. Journal of Business Venturing, 23 (4), 482-496.

Ho, R. (2006). Handbook of Univariate 
and Multivariate Data Analysis and Interpretation with SPSS, Chapman \& Hall/CRC, Taylor \& Francis Group.

Jiménez-Jiménez, D., \& Sanz-Valle, R. (2011). Innovation, organizational learning, and performance. Journal of Business Research, 64 (1), 408-417.

Kawakami, T., MacLachlan, D. L., \& Stringfellow, A. (2012). New venture performance in China, Japan and The United States: The impact of formalized market information process. Journal of product Innovation Management, 29 (2), 275-287.

Keh, H. T., Nguyen, T. T. M., \& Ng, H. P. (2007). The effects of entrepreneurial orientation and marketing information on the performance of SMEs. Journal of Business venturing, 22, 592-611.

Leskovar-Spacapan, G., \& Bastic, M. (2007). Differences in organizations' innovation capability in a transition economy: Internal aspect of the organizations' strategic orientation. Technovation, 27 (9), 533-546.

Levine, C., (2007). Neural correlates of corporate camaraderie and teamwork. Annals of the New York. Academy of Sciences, 1118, 102-108.

Love, J. H., \& Roper, S. (2015). SME innovation, exporting and growth: A review of existing evidence. International Small Business Journal, 33 (1), 28-48.

Maslow, A. (1968). Creativity in selfactualizing people. Toward a psychology of being. New York: Van Nostrand Reinhold Company.

Molina, M. L., Montes-Lorens, J., \& Ruiz-Moreno A. (2007). Relationship between quality management practices and knowledge transfer. Journal of Operations Management, 25 (3), 682-701.

Moorman, C. (1995). Organizational market information processes: Cultural antecedents and new product outcomes. Journal of Marketing Research, 32 (3), 318-335.

Narver, J. C., \& Slater, S. F. (1990). The effect of a market orientation on business profitability. Journal of Marketing 54 (4), 2035.

Naude, W. (2010). Entrepreneurship, Developing countries, and development economics: New approaches and insights. Small Business Economics, 34 (1), 1-12.

Nikolić M., Despotović, D., \& Cvetanović, D. (2015). Barriers to innovation in SMEs in the republic of Serbia. Ekonomika, 61 (4), 89-96.

Nunnally, J. C. (1978). Psychometric Theory, 2nd Edition. McGraw-Hill, New York.

Nystrom, H. (1993). Creativity and entrepreneurship. Creativity and Innovation Management, 2 (4), 237-242.

Schumpeter, J. A. (1934). Theory of economic development: An inquiry into profits, capital, credit, interest, and the business cycle. New York: Oxford University Press.

Shalley, C. E. (1995). Effects of coaction, expected evaluation, and goal setting on creativity and productivity. Academy of Management Journal, 38 (2), 483-503.

Shalley, C. E., \& Gilson, L. L. (2004). What leaders need to know: A review of social and contextual factors that can foster or hinder creativity. The Leadership Quarterly, 15 (1), 33-53.

Silvia, P. J., Kaufman, J. C., \& Pretz, J. E. (2009). Is creativity domain-specific? Latent class models of creative accomplishments and creative self-descriptions. Psychology of Aesthetics, Creativity, and the Arts, 3 (3), 139-148.

Soo, C. W., Devinney, T. M., \& Midgley, D. F. (2007). External knowledge 
acquisition, creativity and learning in organisational problem solving. International Journal of Technology Management, 38 (1-2), 137-159.

Sparkes, J. R., \& Miyake, M. (2000). Knowledge transfer and human resource development practices: Japanese firms in Brazil and Mexico. International Business Review, 9 (5), 599-612.

Stewart, G. L., \& Barrick, M. R. (2000). Team structure and performance: assessing the mediating role of intrateam process and the moderating role of task type, Academy of Management Journal, 43 (2),135-148.

Szulanski, G. (1996). Exploring internal stickiness: Impediments to the transfer of best practice within the firm. Strategic Management Journal, 17 (S2), 27-43.

Tang, J. (2008). Environmental munificence for entrepreneurs: entrepreneurial alertness and commitment. International Journal of Entrepreneurial Behaviour and Research, 14 (3), 128-151.

Tata, J., \& Prasad, S. (2004). Team selfmanagement, organizational structure, and judgments of team effectiveness. Journal of Managerial Issues, 16 (2), 248-265.

Tenenhaus, M., Vinzi, V. E., Chatelin, Y. M., \& Lauro, C. (2005). PLS path modeling. Compulational Statistics and Data Analysis, 48 (1), 159-205.

Wilson, F., Kickul, J., \& Marlino, D. (2007). Gender, entrepreneurial self-efficacy, and entrepreneurial career intentions: Implications for entrepreneurship education. Entrepreneurship Theory and Practice, 31 (3), 387-406.

Wood, R., \& Bandura, A. (1989). Social cognitive theory of organizational management. Academy of Management Review, 14 (3), 361-384.

Yang, H. L., \& Cheng, H. H. (2009). Creative self-efficacy and its factors: An empirical study of information system analysts and programmers. Computers in Human Behavior, 25 (2), 429-438.

Zhang, P., \& Ng, F. F. (2012). Attitude toward knowledge sharing in construction teams. Industrial Management \& Data Systems, 112 (9), 1326-1347.

Živković, D., Živković, Ž ., Manasijević, D., \& Kostadinović, M. (2010). Investigation of the knowledge combination interrelations between SMEs and consumer/supplier network. Serbian Journal of Management, 5 (2), 261-269. 